\title{
Review of the genus Progrillotia Dollfus, 1946 (Cestoda: Trypanorhyncha), with a redescription of Progrillotia pastinacae Dollfus, 1946 and description of Progrillotia dasyatidis sp. $n$.
}

\author{
Ian Beveridge ${ }^{1}$, Lassad Neifar $^{2}$ and Louis Euzet ${ }^{3}$ \\ ${ }^{1}$ Department of Veterinary Science, University of Melbourne, Veterinary Clinical Centre, Werribee, Victoria, Australia; \\ ${ }^{2}$ Département de Biologie, Faculté des Sciences, Université de Sfax, 3038 Sfax, Tunisie; \\ ${ }^{3}$ Station Méditerranéenne de l'Environment Littoral, Université Montpellier 2, 34200 Sète, France
}

Key words: Cestoda, Trypanorhyncha, Progrillotia, revision, Dasyatis, Tunisia, France

\begin{abstract}
Progrillotia pastinacae Dollfus, 1946 (Cestoda: Trypanorhyncha) is redescribed from the spiral valve of Dasyatis pastinaca (Linnaeus) (Dasyatididae) from the coast of France. Progrillotia dasyatidis sp. $\mathrm{n}$. is described from the spiral valves of Dasyatis tortonesei Capapé (Dasyatididae) from the Mediterranean in the Gulf of Gabès (Tunisia) and D. pastinaca from the Bassin d'Arcachon (France). The new species differs from congeners in having, on the tentacles, a single rather than two rows of intercalary hooks and fewer testes. The generic definition is emended based upon the new species, the redescription of $P$. pastinacae Dollfus, 1946 and re-examination of the type specimen of P. louiseuzeti Dollfus, 1969. Important additional characters noted are that the tentacular hooks are solid, a prebulbar organ is present and that there are gland cells attached to the retractor muscle within the bulb. A cladistic analysis suggests that the genus is closely allied with the Eutetrarhynchidae. Progrillotia dollfusi Carvajal et Rego, 1983 is provisionally excluded from the genus as the adult of the species is unknown and a key character of the genus is that the testes are pre-ovarian.
\end{abstract}

The trypanorhynchan cestode subgenus Progrillotia was erected by Dollfus (1946) within the genus Grillotia Guiart, 1927 to accommodate a species of cestode from the spiral valve of the stingray Dasyatis pastinaca (Linnaeus, 1758) collected at Concarneau on the Atlantic coast of France. The type species, Grillotia $(P$.$) pastinacae, possessed two bothridia and an atypical$ heteroacanthous armature, but differed from species of Grillotia in the anatomy of the adult with the testes lying exclusively anterior to the ovary, hence the name Progrillotia. Subsequently, Dollfus (1969) added a second species, P. louiseuzeti, collected from Dasyatis violacea (Bonaparte, 1832), from Sète, on the Mediterranean coast of France. Dollfus (1969) elevated Progrillotia to generic rank, noting that in addition to the disposition of the testes anterior to the ovary, the two species of Progrillotia possessed an armature that differed from Grillotia in lacking a continuous band of small hooks on the external surface of the tentacle. Both species of Progrillotia were incompletely described and the critical details of the distribution of hooks on the external surface of the metabasal region of the tentacle were not described. In addition, the features of the terminal genitalia were not described.

More recently, Carvajal and Rego (1983) described $P$. dollfusi from the teleost Cynoscion striatus (Cuvier, 1829) in Brazil, based exclusively on the plerocercus. The features of the mature segment of this species are not known and hence the critical feature of testis distribution remains to be established. The species has been redescribed by Pereira (1998).

A preliminary cladistic analysis of genera of the Trypanorhyncha by Beveridge et al. (1999) failed to resolve the position of the genus Progrillotia within the order, placing it between the clade containing the families Eutetrarhynchidae, Tetrarhynchobothriidae, Rhinoptericolidae, Shirleyrhynchidae and Mixodigmatidae on the one hand and the sister clade containing the families Grillotiidae, Otobothriidae, Pterobothriidae, Mustelicolidae, Lacistorhynchidae, Dasyrhynchidae and Hornelliellidae on the other (Beveridge et al. 1999, fig. 3). In phenetic classifications, the genus had been placed in the Grillotiidae by Campbell and Beveridge (1994) and the Lacistorhynchidae by Palm (1997). Thus in both phenetic and cladistic studies, the position of the genus remains unresolved, due largely to inadequate information on its morphology.

In the current paper, a new species of Progrillotia is described from the stingray Dasyatis tortonesei Capapé, 1977 from the Mediterranean and additional features of the type species, $P$. pastinacae, are provided from new specimens collected from the type host, D. pastinaca, in the Golfe de Gascogne. The type of the third species, $P$. louiseuzeti, was also examined. The key morphological features of the genus are re-examined, the genus is redefined and an attempt made to resolve its taxonomic and phylogenetic affiliations. 


\section{MATERIALS AND METHODS}

Collection of hosts and preservation of cestodes. Specimens of Dasyatis tortonesei were collected by L. Neifar using either net or hand-line from the Gulf of Gabès, Tunisia (Neifar et al. 2000). Rays were identified following McEachran and Capapé (1984). Specimens of Dasyatis pastinaca were collected at Arcachon, on the Atlantic coast of France. Fish were dissected as soon as possible after capture. The spiral valve was tied off at the posterior extremity to prevent loss of contents and injected with a solution containing $8 \%$ formalin. Spiral valves were then stored in $5 \%$ formalin prior to dissection. Following removal from the spiral valve, cestodes were stored in $70 \%$ ethanol.

Cestodes were stained with Celestine blue, dehydrated in ethanol, cleared in methyl salicylate and mounted in Canada balsam. Drawings were made with the aid of a drawing tube attached to an Olympus BH microscope. Measurements were made with an ocular micrometer and are presented in micrometres $(\mu \mathrm{m})$ unless otherwise stated as the range followed, in parentheses, by the mean and number of specimens measured. Specimens have been deposited in the Muséum national d'Histoire naturelle, Paris (MNHN) or in The Natural History Museum, London (BMNH).

Type specimens of Progrillotia pastinacae and Progrillotia louiseuzeti in MNHN were examined and drawings of specific morphological features made from them.

Terminology for morphological characters peculiar to the trypanorhynchs follows Dollfus (1942) and Campbell and Beveridge (1994). Tentacular hooks of the principal rows are numbered from the internal to the external surface of the tentacle, with hooks of the antibothridial surface indicated by a prime following Dollfus (1942). Intercalary hooks are shown in black and are lettered rather than numbered, again with a prime indicating those of the antibothridial surface (Dollfus 1942).

To further investigate the phylogenetic relationships of the genus Progrillotia, the full character matrix used by Beveridge et al. (1999) as well as the same outgroups was re-examined following recoding of characters based on the description presented below. Character codings altered were: 7 : prebulbar organ present (1); 16: uterine pore absent (1); 17: uterus, straight, tubular (0); 20: gland cells present within bulb (1); 28: hooks solid (0) and 33: armature heteroacanthous atypical (1). Analyses were run using PAUP 3.1.1 together with the same settings employed by Beveridge et al. (1999). The strict and $50 \%$ consensus tree was obtained and branches with low frequencies of occurrence were collapsed as described by Beveridge et al. (1999).

Host nomenclature follows Eschmeyer (1998).

\section{RESULTS}

Progrillotia pastinacae Dollfus, 1946

Figs. 1-10

T y p e m a t e r i a 1: From spiral valve of Dasyatis pastinaca (Linnaeus, 1758), Concarneau, Atlantic coast of Brittany, France $\left(47^{\circ} 53^{\prime} \mathrm{N}, 3^{\circ} 55^{\prime} \mathrm{W}\right)$, coll. R. Legendre, MNHN, Bd 28, slides 81-82.

M a t e r i a 1 e x a m i n e d: Types; 136 specimens from $D$. pastinaca, Arcachon, Golfe de Gascogne, France
(444ㅇ'N, 111'W), coll. L. Euzet, 17.vi.1953, 25.vi.1953, representative specimens deposited: MNHN 61HG, CIX, slide 182.

Description. Mature specimens 2.04-3.82 (2.75, $\mathrm{n}=$ 10) $\mathrm{mm}$ long composed of $6-8(7.2, \mathrm{n}=10)$ segments (Fig. 6); maximum width of strobila $0.12-0.25(0.17, \mathrm{n}$ $=10) \mathrm{mm}$. Scolex acraspedote, 0.96-1.06 $(1.01, \mathrm{n}=10)$ $\mathrm{mm}$ long, maximum width in pars vaginalis $0.15-0.20$ $(0.17, \mathrm{n}=10) \mathrm{mm}$ (Fig. 7); pars bothridialis $0.18-0.23$ $(0.21, \mathrm{n}=10) \mathrm{mm}$ long; two elongate sub-cordiform bothridia without distinct margins or a distinct posterior indentation, width of bothridium $0.15(0.13-0.17, \mathrm{n}=9)$ $\mathrm{mm}$ (Fig. 7). Pars vaginalis $0.40-0.51(0.46, \mathrm{n}=10) \mathrm{mm}$ long; tentacular sheaths sinuous. Bulbs elongate, 0.44$0.65(0.54, \mathrm{n}=10) \mathrm{mm}$ long, 0.06-0.08 $(0.07, \mathrm{n}=10)$ mm wide, length : width ratio 6.7-10.4 $(7.8, \mathrm{n}=10)$ (Fig. 9); prominent prebulbar organ at junction of sheath with bulb (Fig. 9); retractor muscle originates at base of bulb, posterior part of retractor surrounded within bulb by linear array of gland cells; bulbs project into pars proliferans scolecis. Scolex ratio, pars bothridialis : pars vaginalis : pars bulbosa $1: 2.20: 2.56$.

Maximum length of everted tentacles $0.31 \mathrm{~mm}$; tentacles without basal swelling, 23-31 $(28, \mathrm{n}=10)$ in diameter at base, $23-27(26, \mathrm{n}=10)$ in metabasal region.

Armature heteroacanthous, atypical; hooks solid. Basal armature consists of 2-3 rows of hooks beginning on internal surface (Fig. 1), terminating on external surface (Fig. 3); hooks with elongate, slender, strongly recurved blade, length 10-20 $(15, \mathrm{n}=5)$, base elongate with blunt guard, 8-15 $(10, \mathrm{n}=5)$, diminishing in size from internal to external surface. Metabasal armature consists of ascending rows of 5 , sometimes 6 , hooks beginning on internal surface, terminating on external surface (Fig. 3). Prominent space between hooks 1 and $1^{\prime}$ on internal surface (Fig. 1). Hooks 1(1') large, uncinate with thickened base, length $21-27(25, \mathrm{n}=10)$, base 20-24 (23, n = 10) (Fig. 4); hooks 2(2') erect, falcate, with slender blade, length $21-27(25, \mathrm{n}=10)$, base 13-14 (14, $\mathrm{n}=10)$; hooks 3(3') falcate, slightly longer than 2(2') but with narrower base, length 27 (23$29, \mathrm{n}=10)$, base $7-10(8, \mathrm{n}=10)$; hooks $4\left(4^{\prime}\right)$ falcate, shorter than 3(3') with less curved blade and with slightly narrower base, length 20-25 $(22, \mathrm{n}=10)$, base 5-8 $(7, \mathrm{n}=10)$; hooks $5\left(5^{\prime}\right)$ falcate, considerably shorter than 4(4'), length $13-18(16, \mathrm{n}=10)$, base 5-8 $(6, \mathrm{n}=10)$; hooks $6\left(6^{\prime}\right)$ present in some but not most rows, falcate, short blade, length $10-13(11, \mathrm{n}=4)$, base 4-7 (5, n = 4) (Fig. 4). Intercalary hooks generally arranged in two rows, commencing between hooks 1(1') and 2(2') (Figs. 2, 3, 5); first row consisting of single, small, falcate hook (a(a')) followed by 3 hooks (b(b')d(d')) with slender, recurved blade but with obtuse base (Fig. 5); hooks diminish in size along row; posterior row of two tiny falcate hooks (e(e'), $\left.\mathrm{f}\left(\mathrm{f}^{\prime}\right)\right)$, second hook only clearly visible in bothridial views; hook length 4-8 (6, n $=10)$, base $2-7(3, \mathrm{n}=10)$; anterior row of intercalary 

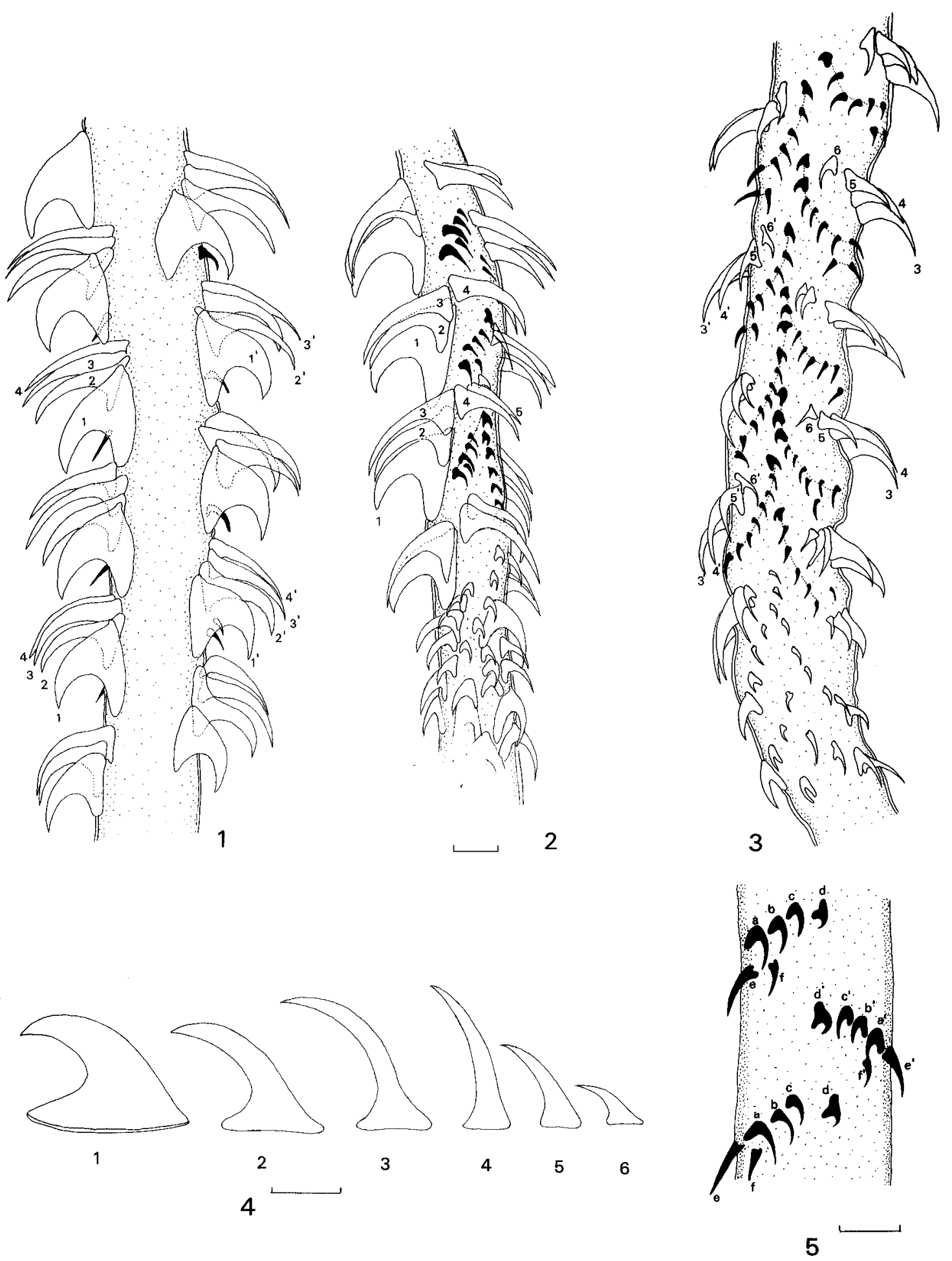

Figs. 1-5. Tentacular armature of Progrillotia pastinacae Dollfus, 1946 from Dasyatis pastinaca. Fig. 1. Metabasal tentacular armature, internal surface of tentacle. Fig. 2. Basal and metabasal armature, antibothridial surface of tentacle. Fig. 3. Basal and metabasal tentacular armature, external surface. Fig. 4. Profiles of hooks 1(1') to 6(6') from the principal rows. Fig. 5. Arrangement of intercalary rows of tentacular hooks, external surface, showing three hooks, a(a')-c(c') with broad base and slender recurved blade, hooks d(d') uncinate with broad base and short, robust, recurved blade, and a second row of hooks (e-f) composed of spiniform hooks. Hooks of principal rows are numbered 1-6 on the antibothridial surface and 1'-6' on the bothridial surface. Scale bars $=0.01 \mathrm{~mm}$. 

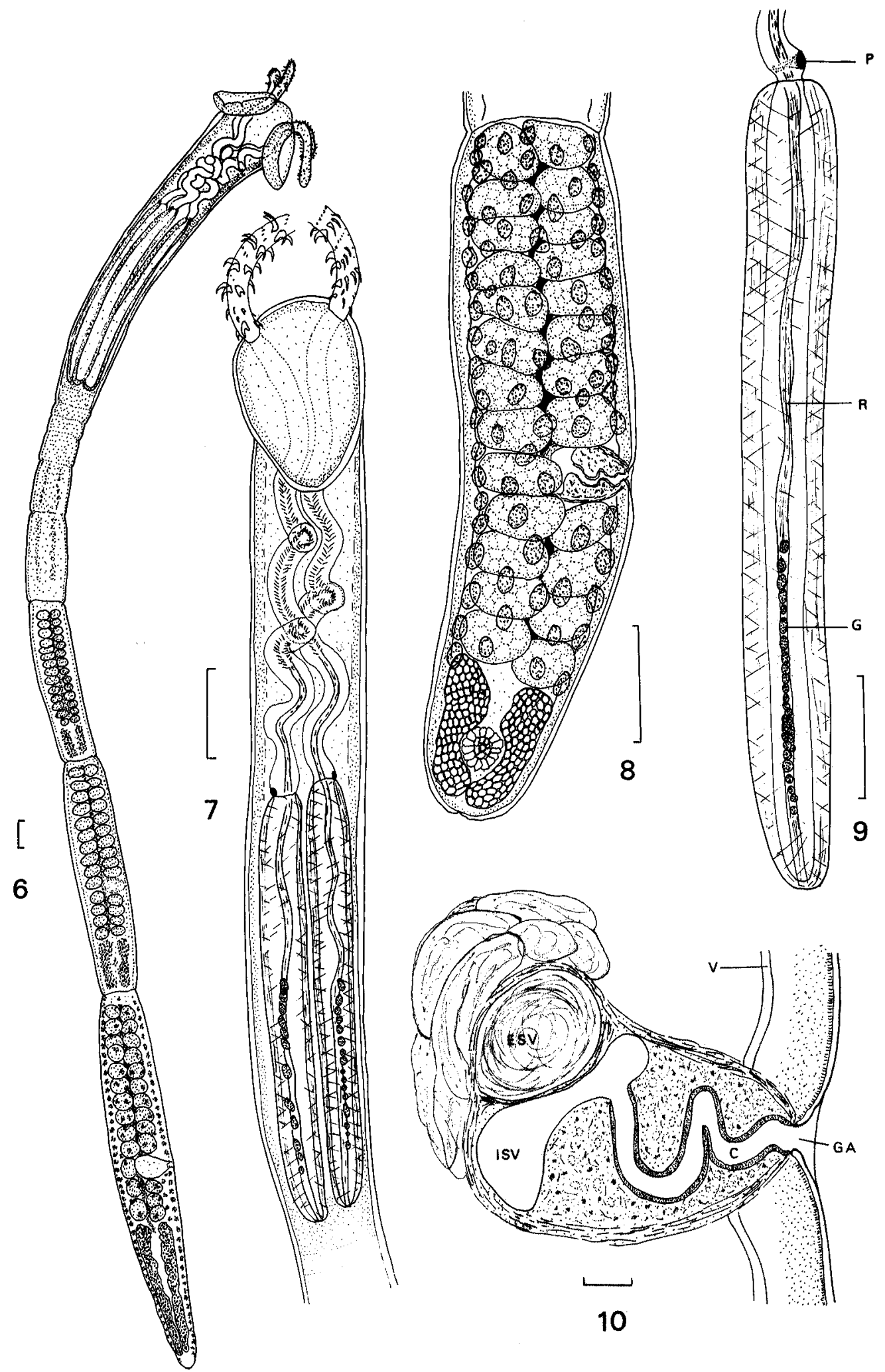

Figs. 6-10. Progrillotia pastinacae Dollfus, 1946 from Dasyatis pastinaca. Fig. 6. Entire mature worm. Fig. 7. Scolex. Fig. 8. Mature segment. Fig. 9. Bulb showing retractor muscle (R), glands attached to retractor muscle $(\mathrm{G})$ and prebulbar organ $(\mathrm{P})$ at anterior end of bulb. Fig. 10. Cirrus sac showing unarmed cirrus (C) leading from genital atrium (GA) to internal seminal vesicle (ISV) and adnate external seminal vesicle (ESV), with ventral osmoregulatory canal (V). Scale bars: Figs. 6-9 = 0.1 mm; Fig. 10 $=0.01 \mathrm{~mm}$. 
hooks terminates in distinctive uncinate hook, $3-5(4, \mathrm{n}$ $=10)$ in length, base $3-5(4, n=10)$; in basal and metabasal regions, intercalary rows consist of series of ascending arrays composed of 8-10 hooks; hooks initially spiniform; final hooks of intercalary row enlarged, uncinate (Fig. 3).

Segments acraspedote. Mature segments $0.35-1.15$ $(0.76, \mathrm{n}=10) \mathrm{mm}$ long, maximum width $0.13-0.24$ $(0.16, \mathrm{n}=10) \mathrm{mm}$ (Fig. 8). Genital pores alternate irregularly, in shallow depression of segment margin, $0.16-0.61(0.37, \mathrm{n}=10) \mathrm{mm}$ from anterior extremity. Testes preovarian, arranged in two parallel columns in segment; total number of testes 20-28 $(24, \mathrm{n}=5)$, arranged as $10-14(12, \mathrm{n}=10)$ antiporal and $10-14(12$, $\mathrm{n}=10)$ poral, with $6-10(8, \mathrm{n}=10)$ anterior to cirrus sac, 3-4 $(3, \mathrm{n}=10)$ posterior to cirrus sac; testis diameter $47-70(59, \mathrm{n}=10)$. Cirrus sac $62-98(78, \mathrm{n}=5)$ by $43-59(51, \mathrm{n}=5)$; cirrus everted in one segment, unarmed. Cirrus sinuous, leads to crescentic internal seminal vesicle adjacent to proximal pole; adnate external seminal vesicle on antero-median aspect of cirrus sac (Fig. 10); vas deferens coils posteriorly from external seminal vesicle towards ovarian isthmus. Vagina opens to genital atrium at same level as cirrus sac, runs medially then posteriorly towards ovary. Ovary in posterior part of segment, 4-lobed, H-shaped in dorsoventral view, lobes 101-312 (211, $\mathrm{n}=5)$ long, 31-39 (35, $\mathrm{n}=$ 5) wide. Mehlis' gland immediately posterior to ovarian isthmus, 30 in diameter. Vitelline follicles $16-27$ (23, n $=10$ ) in diameter, cortical, scattered around margin of segment. Uterus simple, tubular, reaching anterior margin of segment. Gravid segments not seen.

\section{Progrillotia dasyatidis sp. $\mathrm{n}$.}

Figs. 11-19

T y p e m a t e r i a 1: Holotype from spiral valve of Dasyatis tortonesei, Gulf of Gabès. Zarzis, Tunisia $\left(33^{\circ} 15^{\prime} \mathrm{N}\right.$, $\left.11^{\circ} 00^{\prime} \mathrm{E}\right)$, coll. L. Neifar, 31.v.1997, MNHN 60HG, CIX no. $173 ; 13$ paratypes from spiral valve of $D$. tortonesei, Gulf of Gabès, Sfax, Tunisia ( $\left.34^{\circ} 45^{\prime} \mathrm{N}, 10^{\circ} 50^{\prime} \mathrm{E}\right)$, coll. L. Neifar, 18.ii.1998, MNHN 60HG, CIX no. 174-181, BMNH 2003.5.6.1-5.

Additional material exa mined: 13 specimens from Dasyatis pastinaca, Arcachon, France $\left(44^{\circ} 40^{\prime} \mathrm{N}\right.$, $1^{\circ} 11^{\prime}$ W), coll. L. Euzet, 17.vi.1953, MNHN 62HG, CIX, slide 183 .

E t y m o log y: The new species is named after the genus of host, Dasyatis, in which members of the genus occur.

Description (from type series). Gravid specimen (holotype) $2.57 \mathrm{~mm}$ long, composed of 4 segments (Fig. 15). Scolex acraspedote $0.61-0.83(0.73, \mathrm{n}=10) \mathrm{mm}$ long, maximum width in pars vaginalis $0.13-0.20(0.16$, $\mathrm{n}=10) \mathrm{mm}$; pars bothridialis $0.15-0.22(0.20, \mathrm{n}=10)$ $\mathrm{mm}$ long; two elongate sub-cordiform bothridia without distinct margins or a distinct posterior indentation, width of bothridium $0.11 \mathrm{~mm}$ (single measurement) (Fig. 16). Pars vaginalis $0.28-0.46(0.37, \mathrm{n}=10) \mathrm{mm}$ long; tentacular sheaths slightly sinuous. Bulbs elon- gate, $0.30-0.38(0.33, \mathrm{n}=10) \mathrm{mm}$ long, $0.04-0.07$ $(0.05, \mathrm{n}=10) \mathrm{mm}$ wide, length $:$ width ratio $4.75-8.80$ $(6.47, \mathrm{n}=10)$ (Fig. 19); pars proliferans scolecis 0.03$0.06(0.04, \mathrm{n}=10) \mathrm{mm}$ long; prominent prebulbar organ at junction of sheath with bulb (Fig. 19); retractor muscle originates at base of bulb, surrounded within bulb by numerous gland cells; bulbs project into pars proliferans scolecis.

Maximum length of everted tentacles $0.33 \mathrm{~mm}$; tentacles without basal swelling, 21-31 $(25, \mathrm{n}=10)$ in diameter at base, $15-23(20, \mathrm{n}=10)$ in metabasal region. Armature heteroacanthous, atypical; hooks solid. Basal armature consists of two rows of uncinate hooks with sharply recurved blades and elongate bases (Figs. $11,12)$, arranged in ascending rows beginning on internal surface; initial hooks in rows 8.6-14.0 $(11.0, \mathrm{n}=10)$ long, base 7.0-11.7 $(9.4, \mathrm{n}=10)$, diminishing in size gradually along row towards external surface (Fig. 12). Metabasal armature composed of half rows of 6 hooks arranged in ascending half circles (Fig. 12); prominent space between hooks 1(1') on internal surface of tentacle (Fig. 11). Hooks 1(1') large, uncinate, with long base, 13.3-18.7 (16.0, $\mathrm{n}=10)$ long, base 13.0-17.2 $(15.5, \mathrm{n}=10)$ (Fig. 14). Hooks 2(2') uncinate, as long as hooks $1\left(1^{\prime}\right)$ but with shorter base, 11.7-19.5 (16.0, $\mathrm{n}=$ 10) long, base 6.2-11.7 (9.4, $\mathrm{n}=10)$. Hooks 3(3') erect, falcate, blade long, base short, 15.6-19.5 $(17.6, \mathrm{n}=10)$ long, base $5.5-8.6(6.8, \mathrm{n}=10)$. Hooks $4\left(4^{\prime}\right)$ falcate, shorter than 3(3'), with narrower base, 10.9-14.0 (12.7, $\mathrm{n}=10)$ long, base 4.7-6.2 (5.7, $\mathrm{n}=10)$. Hooks 5(5') similar to previous hooks, $7.8-13.3(11.2, \mathrm{n}=10)$ long, base 3.1-5.5 (4.6, $\mathrm{n}=10)$. Hooks 6(6') small, erect, 4.7-7.0 (5.6, $\mathrm{n}=10)$ long, base 3.1-4.7 (3.7, $\mathrm{n}=5)$. Single row of intercalary hooks between each principal row (Fig. 13); intercalary hooks 2.3-5.5 (3.4, $\mathrm{n}=10)$ long, base $0.8-2.3(1.9, \mathrm{n}=5)$. No intercalary rows in basal region; initial intercalary rows appear between principal rows 1 and 2, composed of 2-3 hooks (Figs. $12,13)$; remaining intercalary rows composed of 5-7 hooks arranged in arc, beginning at level of hooks 3(3'), extending beyond principal row to middle of external surface (Fig. 13). No additional hooks on external surface of tentacle apart from intercalary hooks. In basal region of external surface, distal hooks of each intercalary row enlarged, uncinate, with broad base and short broad blade (Fig. 14).

Segments acraspedote; mature specimens with 2-4 segments; single gravid specimen with 4 segments. Mature segments $0.38-0.98(0.62, \mathrm{n}=10) \mathrm{mm}$ long, maximum width $0.10-0.21(0.16, \mathrm{n}=10) \mathrm{mm}$ (Fig. 17). Genital pores alternate irregularly, in shallow depression of segment margin, $0.16-0.32(0.23, \mathrm{n}=5) \mathrm{mm}$ from anterior extremity. Testes preovarian, arranged in two parallel columns in segment (Fig. 17); total number of testes $16-23(18, \mathrm{n}=5)$, arranged as $10-11$ antiporal, 8-12 poral, with 5-8 anterior to cirrus sac, 3-4 posterior to cirrus sac; testis dimensions $45-60(55, \mathrm{n}=10)$ by 

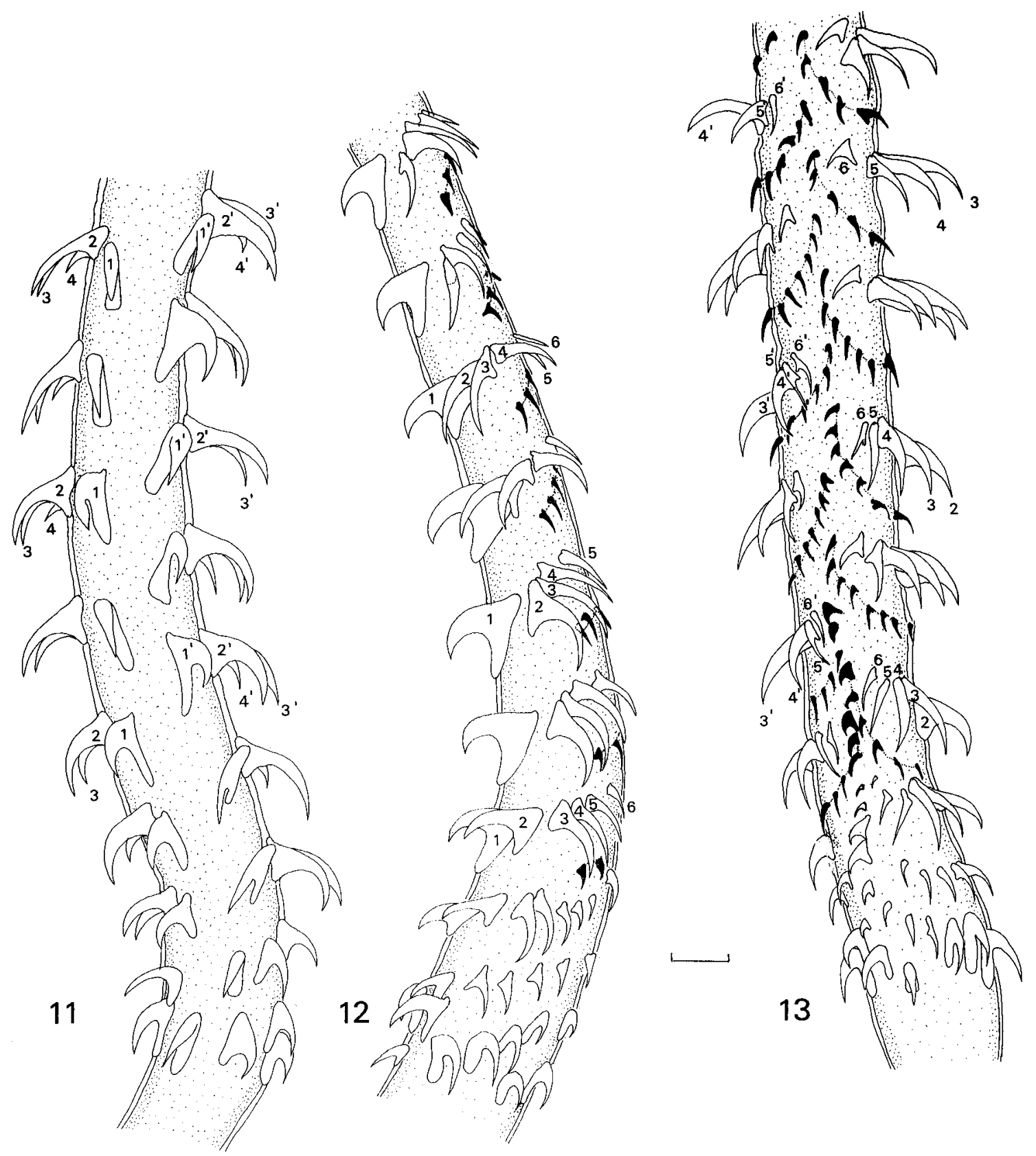

\section{4}
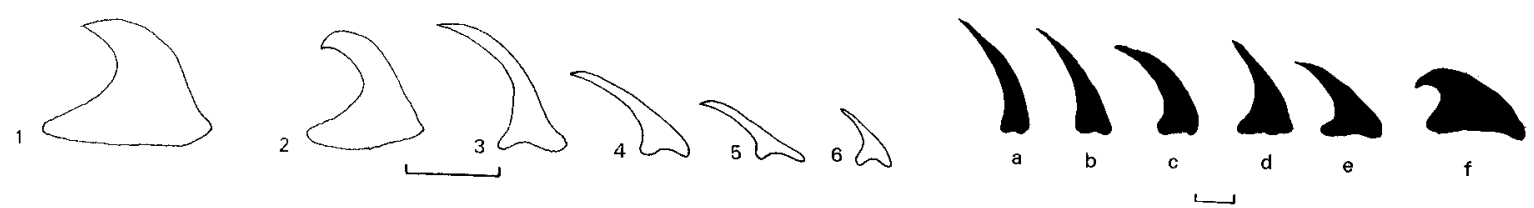

Figs. 11-14. Tentacular armature of Progrillotia dasyatidis sp. n. from Dasyatis tortonesei. Fig. 11. Basal and metabasal tentacular armature, internal surface of tentacle. Fig. 12. Basal and metabasal armature, antibothridial surface of tentacle. Fig. 13. Basal and metabasal tentacular armature, external surface. Fig. 14. Profiles of hooks $1\left(1^{\prime}\right)$ to $6\left(6^{\prime}\right)$ from the principal rows and intercalary row near the base of the tentacle. Intercalary hooks are shown in black. Hooks of principal rows are numbered 1-6 on the antibothridial surface and 1' -6 ' on the bothridial surface. Scale bars $=0.01 \mathrm{~mm}$; for intercalary hooks $=0.001 \mathrm{~mm}$. 


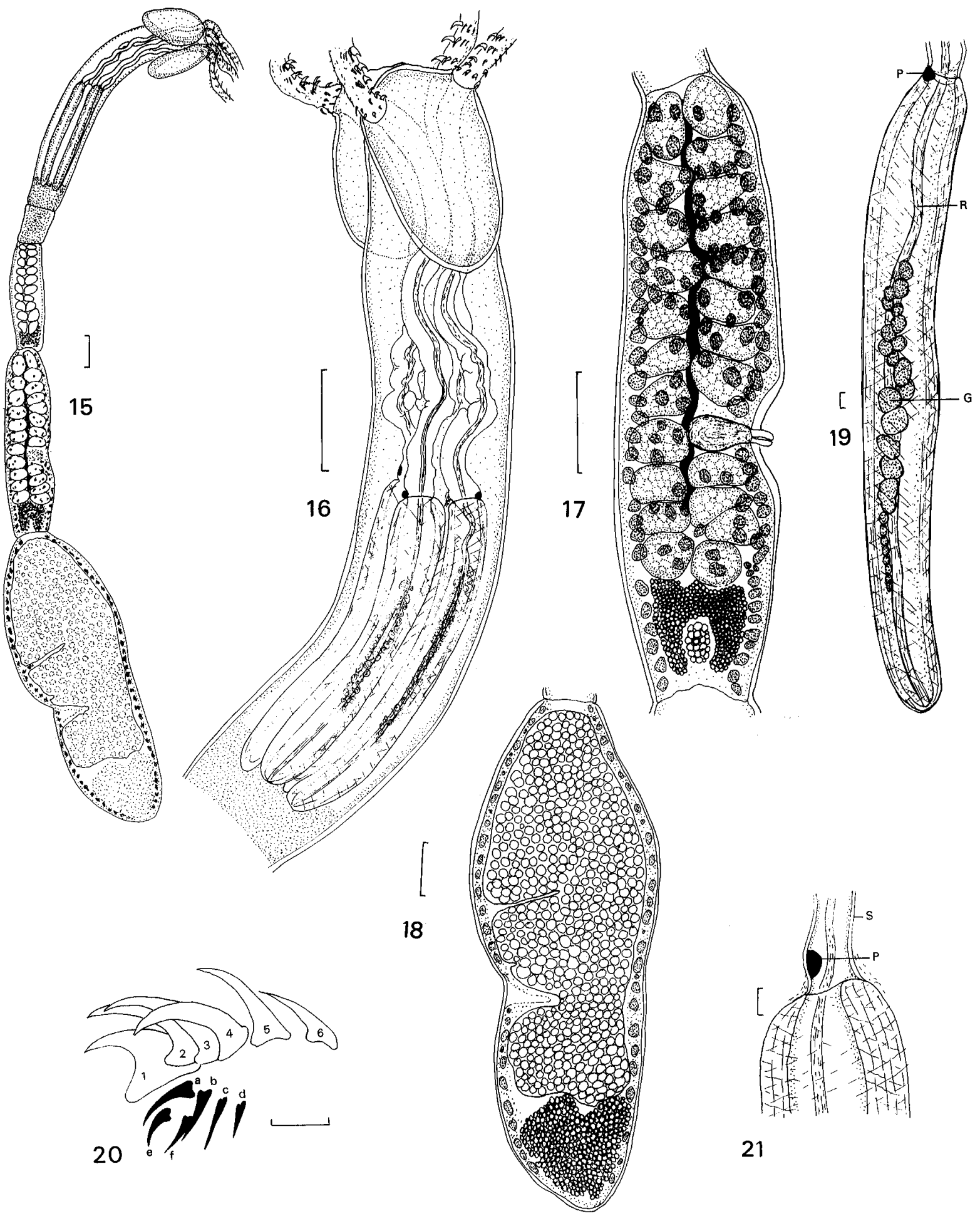

Figs. 15-19. Segments of Progrillotia dasyatidis sp. n. from Dasyatis tortonesei. Fig. 15. Entire cestode. Fig. 16. Scolex. Fig. 17. Pre-mature segment. Fig. 18. Gravid segment. Fig. 19. Bulb showing prebulbar organ (P) and gland cells $(G)$ within bulb attached to retractor muscle (R). Figs. 20, 21. Progrillotia louiseuzeti Dollfus, 1969, drawn from holotype. Fig. 20. Hooks of principal row and intercalary rows showing 6 hooks in principal row and intercalary rows composed of 4 and 2 spiniform hooks, respectively. Fig. 21. Junction of sheath $(\mathrm{S})$ with bulb showing prebulbar organ $(\mathrm{P})$. Scale bars: Figs. $15-18=0.1 \mathrm{~mm}$; Figs. 19 $21=0.01 \mathrm{~mm}$. 
$35-55(45, \mathrm{n}=10)$. Ovary in posterior part of segment, 4-lobed, H-shaped in dorsoventral view, 100 long, 90 wide. Mehlis' gland immediately posterior to ovarian isthmus, 30 by 20 . Vitelline follicles $20-29(21, \mathrm{n}=10)$ in diameter, cortical, scattered around margin of segment. Terminal genitalia not visible in most specimens; cirrus everted in one segment, unarmed. Uterus simple, tubular, extending in midline almost to anterior extremity of segment. Gravid segment 0.92 by $0.32 \mathrm{~mm}$, genital pore 0.55 from anterior extremity; gravid uterus saccate, filled with eggs (Fig. 18). Eggs spherical, 10 $14(12, \mathrm{n}=10)$ in diameter.

Principal measurements of specimens from $D$. pastinaca. Length of mature specimens 1.09-1.60 (1.36, $\mathrm{n}=7) \mathrm{mm}$; number of segments $2-3(2.9, \mathrm{n}=7)$; length of gravid specimens 1.42 and $2.01 \mathrm{~mm}$; numbers of segments 2 and 3. Scolex length 0.62-0.72 (0.66, $\mathrm{n}=$ 10) $\mathrm{mm}$; scolex width $0.12-0.16(0.14, \mathrm{n}=10) \mathrm{mm}$; pars bothridialis $0.15-0.17(0.16, \mathrm{n}=10) \mathrm{mm}$; pars vaginalis $0.30-0.41(0.37, \mathrm{n}=10) \mathrm{mm}$; bulbs $0.25-0.31$ $(0.27, \mathrm{n}=10) \mathrm{mm}$ long, 0.04-0.06 $(0.05, \mathrm{n}=10) \mathrm{mm}$ wide; length : width 4.57-6.80 (5.21, $\mathrm{n}=10)$. Mature segments $0.33-0.52(0.43, \mathrm{n}=5) \mathrm{mm}$ long by $0.14-0.20$ $(0.16, \mathrm{n}=5) \mathrm{mm}$ wide; genital pore $0.16-0.23(0.19, \mathrm{n}=$ 5 ) from anterior end of segment; number of testes 13-18 $(15, \mathrm{n}=5), 7-9(8, \mathrm{n}=5)$ antiporal, 6-9 $(7, \mathrm{n}=5)$ poral, with $4-6(5, \mathrm{n}=5)$ anterior to cirrus sac, $2-3(2, \mathrm{n}=5)$ posterior to cirrus sac. Gravid segments 0.70 and 0.75 $\mathrm{mm}$ long, 0.24 and $0.27 \mathrm{~mm}$ wide; genital pore 0.34 and $0.37 \mathrm{~mm}$ from anterior end of segment.

\section{Progrillotia loniseuzeti Dollfus, 1969 Figs. 20, 21}

M a t e r i a 1 s t u d i e d : Holotype from spiral valve of Dasyatis violacea (Bonaparte, 1832), Gulf of Lion, Mediterranean, Sète, France $\left(42^{\circ} 25^{\prime} \mathrm{N}, 3^{\circ} 43^{\prime} \mathrm{E}\right)$, coll. L. Euzet, 5.x.1953, MNHN, Bd 16, slide 33.

Additional morphological features not included in original description: armature heteroacanthous, atypical; hooks solid. Principal rows with 6 hooks; intercalary hooks arranged in 2 rows with 4 hooks in anterior row and 2 hooks in posterior row (Fig. 20); external surface of tentacles not visible. Bulbs with prominent prebulbar organ at junction of sheath with bulb (Fig. 21); no distinct gland cells present within bulb, but deeply staining mass of possible gland cells visible adjacent to retractor muscle.

Based on the new species, the redescription of $P$. pastinacae and the re-examination of the type specimen of $P$. louiseuzeti, the definition of Progrillotia given by Campbell and Beveridge (1994) is emended:

\section{Progrillotia Dollfus, 1946}

Small cestodes; scolex acraspedote; 2 elongate bothridia without prominent margins or posterior indentation. Tentacle without basal swelling or distinctive basal armature; hooks solid. Metabasal armature consists of ascending half rows of 6 hooks commencing on internal surface of tentacle; distinct space between hooks 1(1') on internal surface. One or two intercalary rows of hooks present. Prebulbar organ present. Retractor muscle originates at base of bulb. Gland cells attached to retractor muscle within bulb. Segments acraspedote, genital pores marginal, alternate irregularly. Testes preovarian arranged in two longitudinal columns; ovary at posterior extremity of segment. Cirrus sac with adnate external seminal vesicle; vagina opens independently to genital atrium. Vitelline follicles circumcortical. Uterus simple, median, tubular; uterine pore absent. Parasites of Dasyatis spp.

T y p e s p e c i e s : Progrillotia pastinacae Dollfus, 1946.

O t h e r s p e c i e s : Progrillotia louiseuzeti Dollfus, 1969;

Progrillotia dasyatidis $\mathrm{sp} . \mathrm{n}$.

Species provisionally excluded:P. dollfusi Carvajal et Rego, 1983 (see below).

\section{Phylogenetic relationships}

Analysis of the modified character matrix of Beveridge et al. (1999) using PAUP 3.1.1 resulted in 3900 equally parsimonious trees with a length of 165 , a consistency index of 0.285 and a rescaled consistency index of 0.191 . The consensus tree was very similar to that of Beveridge et al. (1999) with the exception that Progrillotia was clearly aligned with the genera of the Eutetrarhynchidae (Fig. 23). The relationships of the genera Rhinoptericola, Shirleyrhynchus, Cetorhinicola, Mixodigma and Halysiorhynchus, identified in the analysis of Beveridge et al. (1999) as being eutetrarhynchid-like but possessing four rather than two bothridia, were less well-resolved in the current analysis, but they remained unequivocally aligned with the Eutetrarhynchidae.

\section{DISCUSSION}

The new species described above belongs to the genus Progrillotia as it possesses an acraspedote scolex with two bothridia, tentacles with an atypical heteroacanthous armature and testes arranged in two longitudinal columns anterior to the ovary. A complete description of the species cannot be given because despite the relatively extensive series of well-preserved specimens available, none possessed fully developed terminal genitalia. Many of the terminal segments were pre-mature and few gravid specimens were available. In these specimens, however, the penultimate segment was immature and the terminal genitalia were not visible. In spite of these deficiencies, the material described represents a new species of Progrillotia and provides significant additional information on the features of the genus. The species described above differs from both $P$. pastinacae and $P$. louiseuzeti in having the intercalary hooks arranged in a single row of 5-7 hooks rather than two rows of approximately four hooks in the anterior row and two hooks in the posterior row (as occurs in both $P$. pastinacae and $P$. louiseuzeti) (Fig. 22). In addition, the new species differs in a number of 
measurements from the known species (Table 1), particularly in the length of the scolex and the lengths of the bulbs, which are shorter than in the congeners. Furthermore, $P$. dasyatidis has fewer testes per segment than in the congeners. Consequently, there is little doubt that the material described from $D$. tortonesei and $D$. pastinaca represents a new species.

The description of the new species and the redescription or re-examination of the type specimens of the known species also provide additional morphological characters for the genus. Most importantly, the hooks of all three species examined are solid rather than hollow. This feature has not been reported previously and is significant as the feature is common in the homeoacanth trypanorhynchs as well as in the eutetrarhynchids (Beveridge et al. 1999). In addition, a prebulbar organ is present in $P$. dasyatidis and there are gland cells attached to the retractor muscle within the bulb. With respect to the prebulbar organ, Dollfus (1946, p. 208) noted that its presence in $P$. pastinacae could not be confirmed but indicated in a footnote that a "refringent" body was present at the anterior end of the bulb. Reexamination of the types as well as the availability of new material has confirmed that this is indeed a prebulbar organ. Dollfus (1969) did not describe a prebulbar organ in $P$. louiseuzeti, but the structure is evident in the holotype (Fig. 21). Similarly, although not described, gland cells are present within the bulb of $P$. pastinacae (Fig. 9), as is the case with $P$. dasyatidis. In the holotype of $P$. louiseuzeti, the scolex is extremely flattened and the contents of bulbs are difficult to discern, but there is a sheet of deeply staining material within the bulb which may have been gland cells. The prebulbar organ and the gland cells within the bulb are important characters defining the eutetrarhynchid clades (clades 3-5) in the study of Beveridge et al. (1999) and the finding of these characters in Progrillotia is likely to affect the affiliations of the genus in cladistic analyses.

The external surface of the metabasal region of the tentacle of $P$. dasyatidis is characterised by a single row of intercalary hooks extending in an arc to the midline of the tentacle (Fig. 13). There are no supernumerary hooks. In P. louiseuzeti, Dollfus (1969, fig. 83) noted that the opposite intercalary rows join in the midline of the tentacle and that there was no separate longitudinal band of hooks (Dollfus, 1969, p. 538). These observations were confirmed in a re-examination of the holotype. In the type species, P. pastinacae, Dollfus (1946, p. 209) noted that on the external surface of the tentacle there were several tiny, well-spaced hooks which were difficult to observe, an observation confirmed by reexamination of the types. Neither Dollfus' description and figures (Dollfus 1946), nor re-examination of the types reveals any band of hooks on the external surface of the tentacle apart from hooks which might belong to the principal rows. However, the new material of $P$. pastinacae described above resolves these uncertainties.

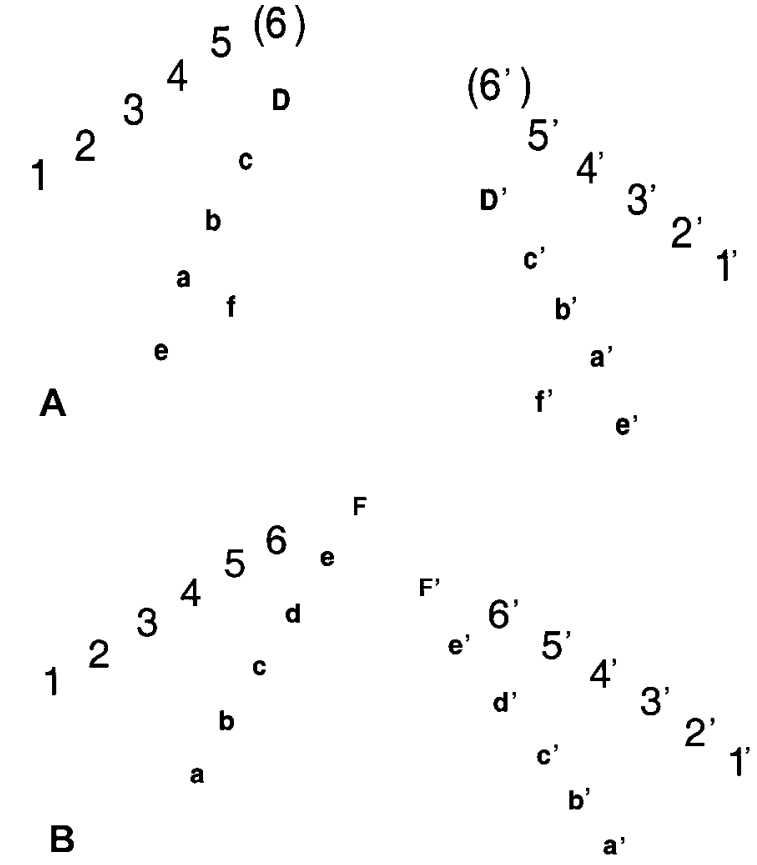

Fig. 22. Schematic representation of armature patterns in the metabasal region of the tentacle of Progrillotia pastinacae Dollfus, 1946 (A) and Progrillotia dasyatidis sp. n. (B). Hooks of the principal rows are shown as numerals 1-6 on the antibothridial surface and 1' -6 ' on the bothridial surface; intercalary hooks as letters $\mathrm{a}-\mathrm{f}$ on the antibothridial surface and a'-f' on the bothridial surface. Upper case D is used in Fig. $22 \mathrm{~A}$ and $\mathrm{F}$ in Fig. 22B to indicate that this hook is enlarged in the metabasal region although not in the distal region of the tentacle.

The new material is from the type host, D. pastinaca, and is also from the Atlantic coast of France, but was collected further south than the type specimens, at Arcachon. The new material provides excellent views of most aspects of the tentacular armature. The redescription presented above confirms virtually all the features described by Dollfus (1946). Occasionally, a sixth hook is present in the principal rows, thereby aligning the species more closely with its congeners. The intercalary rows consist of an anterior row which begins closer to the external surface than the posterior row and consists of three hooklets with strongly recurved, slender blades and a base with a blunt handle. The row terminates in an uncinate hooklet. The second row consists of two spiniform hooklets, though the second hook is not always identifiable. On the external surface of the basal region, the terminal hooks of the row are more robust than those near the origin of the row and the confluence of the larger hooklets from both sides in the middle of the external surface of the tentacle superficially gives the appearance of a chainette-like file of uncinate hooks. A similar pattern occurs in $P$. dasyatidis. However, when the precise position of the hooklets is determined 


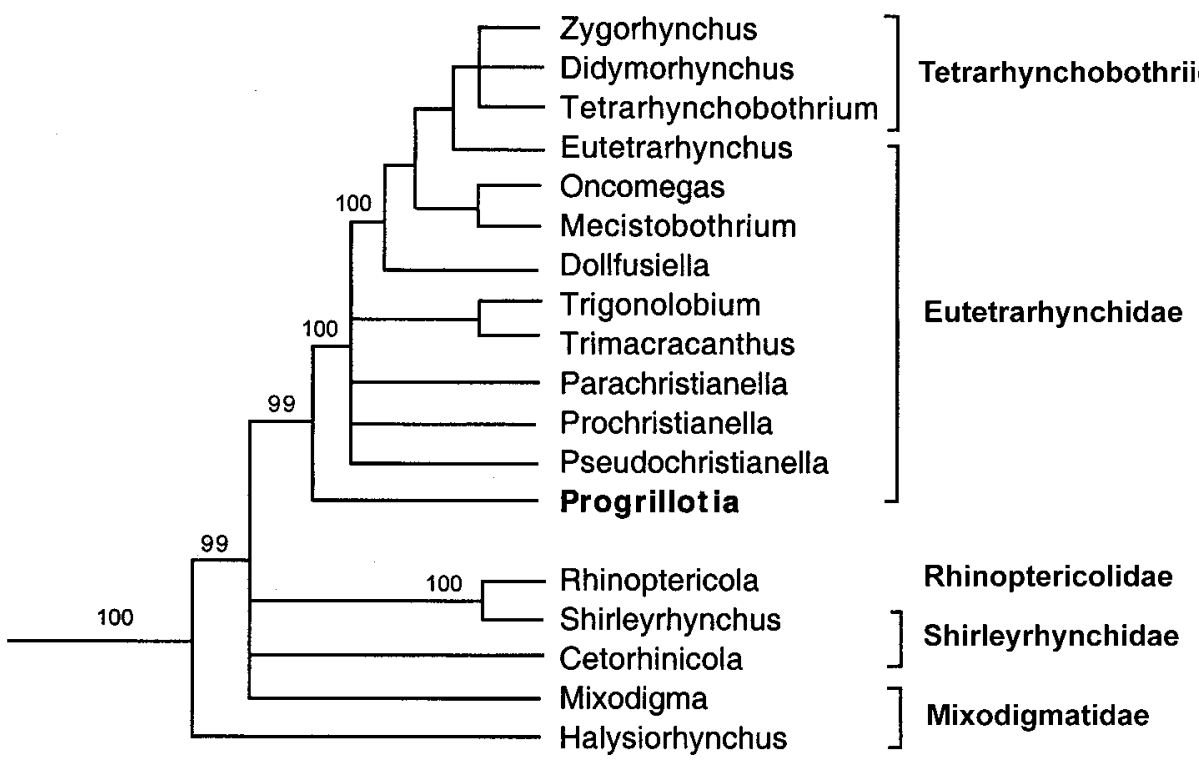

Fig. 23. Part of a cladistic analysis (clades 3-5) of the genera of the Trypanorhyncha using the character matrix of Beveridge et al. (1999) modified as described in the text to include changes to character polarities resulting from the current re-examination of the genus. The entire tree is shown in Beveridge et al. (1999). The position of Progrillotia (in bold) in the re-analysis indicates a close relationship with the genera of the Eutetrarhynchidae.

it is evident that each hooklet occurs in an intercalary row and that there are no hooklets present in addition to the intercalary rows. It is merely the enlargement of the terminal intercalary hooklets in each row and the confluence of the rows that give the appearance of a chainette.

Chainettes restricted to the basal and/or metabasal region of the tentacle are known in the genera Paroncomegas Campbell, Marques et Ivanov, 1999 (see description of Campbell et al. 1999), Dasyrhynchus talismani Dollfus, 1935 (see descriptions by Dollfus 1942, Beveridge and Campbell 1993), Mixodigma leptopetaleum Dailey et Vogelbein, 1982 (see description by Dailey and Vogelbein 1982) and in Pterobothrioides petterae Campbell et Beveridge, 1997 (see description by Campbell and Beveridge 1997), such that their occurrence in Progrillotia would not be a novel phenomenon. However, in Progrillotia, all hooks present on the external surface of the basal region of the tentacle are components of the intercalary rows and cannot be considered to constitute a basal chainette.

The cladistic analysis suggests that Progrillotia is allied to the eutetrarhynchids. In the classifications of Dollfus (1942) and Campbell and Beveridge (1994), the eutetrarhynchids were considered to have typical heteroacanthous armatures and two bothridia. The cladistic analysis of Beveridge et al. (1999) (Fig. 23) included in the same clade as the traditional eutetrarhynchid genera (Eutetrarhynchus Pintner, 1913, Dollfusiella Campbell et Beveridge, 1994, Mecistobothrium Heinz et Dailey, 1974, Oncomegas Dollfus, 1929, Parachristianella Dollfus, 1946, Prochristianella Dollfus, 1946, Pseudo- christianella Campbell et Beveridge, 1990, Trigonolobium Dollfus, 1929, Trimacracanthus Beveridge et Campbell, 1987) others with four rather than two bothridia (Shirleyrhynchus Beveridge et Campbell, 1988 and Cetorhinicola Beveridge et Campbell, 1988) as well as genera with four bothridia and chainettes such as Halysiorhynchus Pintner, 1913 and Mixodigma Dailey et Vogelbein, 1982. It also included Rhinoptericola Carvajal et Campbell, 1975, a genus of atypical heteroacanths with four bothridia. The addition of Progrillotia to the same clade provides the final combination of characters, that is an atypical heteroacanthous armature combined with two bothridia. Thus, the "eutetrarhynchid" clade now consists of cestodes with either two or four bothridia, typical heteroacanthous armatures or atypical heteroacanthous armatures or chainettes, supporting the hypothesis (Beveridge et al. 1999) that armature types within the order are homoplasious.

Prochristianella dollfusi was described initially by Carvajal and Rego (1983) and was redescribed in detail by Pereira (1998). Both descriptions note only four hooks in the principal row, a prominent band of hooks on the external surface of the base of the tentacle, and the description of Pereira (1998) notes that the hooks are hollow and that the retractor muscle originates in the anterior part of the bulb. None of these characters is seen in the species of Progrillotia described above and for these reasons, $P$. dollfusi is provisionally excluded from the genus. It closely resembles species of Grillotia such as G. smarisgora (Wagener, 1854) (see description of Dollfus 1946) and G. australis Beveridge et Campbell, 2001 (see description by Beveridge and Campbell 
Table 1. Comparison of morphological features of species of Progrillotia. Ranges are followed by means in parentheses.

\begin{tabular}{|c|c|c|c|}
\hline & P. pastinacae* & P. louiseuzeti & P. dasyatidis sp. n.* \\
\hline Scolex length (mm) & $0.96-1.06(1.01)$ & 1.9 & $0.61-0.83(0.73)$ \\
\hline Pars bothridialis (mm) & $0.18-0.23(0.24)$ & 0.45 & $0.15-0.22(0.20)$ \\
\hline Pars vaginalis (mm) & $0.40-0.51(0.46)$ & 0.85 & $0.28-0.46(0.37)$ \\
\hline Bulb length (mm) & $0.44-0.65(0.54)$ & 0.88 & $0.30-0.38(0.33)$ \\
\hline Bulb ratio & $6.7-10.4(7.8)$ & 15 & $4.8-8.8(6.5)$ \\
\hline Gland cells in bulb & + & ? & + \\
\hline Prebulbar organ & + & + & + \\
\hline Hooks solid & + & + & + \\
\hline No. of hooks in rows & $5-6$ & 6 & 6 \\
\hline Hook 1(1') $(\mu \mathrm{m})$ & $21-27(25)$ & 24 & $13-19(16)$ \\
\hline Hook 2(2') $(\mu \mathrm{m})$ & $21-27(25)$ & 20 & $12-20(16)$ \\
\hline Hook 3(3’) $(\mu \mathrm{m})$ & $23-29(27)$ & - & $16-20(18)$ \\
\hline Hook 4(4’) $(\mu \mathrm{m})$ & $20-25(22)$ & - & 11-14 (13) \\
\hline Hook 5(5') $(\mu \mathrm{m})$ & $13-18(16)$ & - & $8-13(11)$ \\
\hline Hook 6(6’) $(\mu \mathrm{m})$ & $10-13(11)$ & - & $5-7(6)$ \\
\hline Intercalary hooks & 2 rows, 6 & 2 rows, $4-12$ & 1 row, $5-7$ \\
\hline No. of testes & $20-28(24)$ & 33 & $16-23(18)$ \\
\hline Host & Dasyatis pastinaca & Dasyatis violacea & $\begin{array}{l}\text { Dasyatis tortonesei } \\
\text { Dasyatis pastinaca }\end{array}$ \\
\hline
\end{tabular}

*measurements in text

Table 2. Numbers of specimens of Progrillotia pastinacae Dollfus, 1946 and $P$. dasyatidis sp. n. collected from individuals of Dasyatis pastinaca at Arcachon, France.

\begin{tabular}{|l|c|c|c|}
\hline $\begin{array}{l}\text { Sex } \\
\text { of host }\end{array}$ & $\begin{array}{c}\text { Total length } \\
\text { of host } \\
(\mathrm{cm})\end{array}$ & $\begin{array}{c}\text { No. of } \\
\text { specimens of } \\
\text { P. pastinacae }\end{array}$ & $\begin{array}{c}\text { No. of } \\
\text { specimens of } \\
\text { P. dasyatidis }\end{array}$ \\
\hline Male 1 & 26 & 33 & 0 \\
Male 2 & 41 & 12 & 0 \\
Male 3 & 42 & 25 & 0 \\
Male 4 & 44 & 2 & 6 \\
Male 5 & 45 & 31 & 0 \\
Female 6 & 50 & 28 & 5 \\
\hline
\end{tabular}

2001), but it is not formally allocated to Grillotia because the potential new combination is preoccupied by G. dollfusi Carvajal, 1971. Its taxonomic position will be considered in a revision of Grillotia currently in progress.

Scholz et al. (1993) allocated G. epinepheli to the subgenus Progrillotia (p. 23), apparently because it lacked a prebulbar organ. Its armature, with 8-9 hooks in each principal row and a distinct band of hooks on the external surface, clearly places this species in the genus Grillotia. Scholz et al. (1993) noted that it was most similar to $G$. perelica (Shuler, 1938) and $G$. branchii Shaharom et Lester, 1982.
Neifar et al. (2000) considered the monocotylid monogeneans of $D$. tortonesei to be distinct from those of D. pastinaca, with the oioxenic parasites supporting the taxonomic differences observed in the hosts. They used parasitological evidence to support the taxonomic distinction of $D$. tortonesei, a distinction currently in dispute (Seret and McEachran 1986, Compagno 1999). Current collections of species of Progrillotia are not entirely consistent with this hypothesis, as $P$. dasyatidis appears to occur both in D. pastinaca and P. tortonesei, and at Arcachon, both species may be found in the same individual ray (Table 2). The conclusions must however be tempered with the small number of collections of cestodes made to date, current deficiencies in knowledge of the anatomy of species of Progrillotia, and uncertainties in the true identity of hosts identified as $D$. pastinaca, prior to the recognition of the existence of the species $D$. tortonesei. Consequently, the identity of specimens collected from the western coast of France in the 1950s and considered to be D. pastinaca (see material examined for $P$. dasyatidis) must remain in doubt until more collections are made as both $D$. pastinaca and D. tortonesei occur in this region.

Acknowledgement. We wish to express our sincere thanks to Dr. R.A. Campbell for comments on a draft of the manuscript.

\section{REFERENCES}

BEVERIDGE I., CAMPBELL R.A. 1993: A revision of Dasyrhynchus (Cestoda: Trypanorhyncha), parasitic in elasmobranch and teleost fishes. Syst. Parasitol. 24: 129-157.

BEVERIDGE I., CAMPBELL R.A. 2001: Grillotia australis n. sp. and G. pristiophori n. sp. (Cestoda: Trypano- rhyncha) from Australian elasmobranch and teleost fishes. Syst. Parasitol. 49: 113-126.

BEVERIDGE I., CAMPBELL R.A., PALM H. 1999: Preliminary cladistic analysis of genera of the cestode order Trypanorhyncha Diesing, 1863. Syst. Parasitol. 42: 29-49. 
CAMPBELL R.A., BEVERIDGE I. 1994: Order Trypanorhyncha Diesing, 1863. In: L.F. Khalil, A. Jones and R.A. Bray (Eds.), Keys to the Cestode Parasites of Vertebrates. Commonwealth Agricultural Bureaux International, Wallingford, pp. 51-148.

CAMPBELL R.A., BEVERIDGE I. 1997: Pterobothrioides, a new genus of tapeworms (Cestoda: Trypanorhyncha: Pterobothriidae) from dasyatid stingrays in the eastern Atlantic and Pacific oceans. Syst. Parasitol. 42: 81-91.

CAMPBELL R.A., MARQUES F., IVANOV V.A. 1999: Paroncomegas araya (Woodland, 1934) n. gen. et comb. (Cestoda: Trypanorhyncha: Eutetrarhynchidae) from the freshwater stingray Potamotrygon motoro in South America. J. Parasitol. 85: 313-320.

CARVAJAL J., REGO A.A. 1983: Progrillotia dollfusi sp. n. (Cestoda: Trypanorhyncha) parasito de pescada do litoral brasileiro. Mem. Inst. Oswaldo Cruz 78: 231-234.

COMPAGNO L.J.V. 1999: Checklist of living elasmobranchs. In: W.C. Hamlett (Ed.), Sharks, Skates and Rays: the Biology of Elasmobranch Fishes. Johns Hopkins University Press, Baltimore, pp. 471-498.

DAILEY M.D., VOGELBEIN W. 1982: Mixodigmatidae, a new family of cestode (Trypanorhyncha) from a deep-sea, planktivorous shark. J. Parasitol. 68: 145-149.

DOLLFUS R.-P. 1942: Etudes critiques sur les Tétrarhynques du Muséum de Paris. Arch. Mus. Natl. Hist. Nat., Paris 19 $1-466$.

DOLLFUS R.-P. 1946: Notes diverses sur les Tétrarhynques. Mém. Mus. Natl. Hist. Nat., Paris 22: 179-220.
DOLLFUS R.-P. 1969: De quelques cestodes tétrarhynques (hétéracantes et pécilacanthes) récoltés chez des poissons de la Méditerranée. Vie et Milieu, Série A, 20: 491-542.

McEACHRAN J.D., CAPAPÉ C. 1984: Dasyatidae. In: P.J.P. Whitehead, M.-L. Bauchot, J.-C. Hureau, J. Nielsen and E. Tortonese (Eds.), Fishes of the North-Eastern Atlantic and the Mediterranean. Vol. 1. UNESCO, Paris, pp. 197-202.

ESCHMEYER W.N. 1998: Catalog of Fishes. California Academy of Sciences, San Francisco, 2905 pp.

NEIFAR L., EUZET L., BEN HASSINE O.K. 2000: New species of the Monocotylidae (Monogenea) from the stingray Dasyatis tortonesi Capapé (Euselachii, Dasyatidae) off the Tunisian coast, with comments on host-specificity and the specific identities of Mediterranean stingrays. Syst. Parasitol. 47: 43-50.

PALM H. 1997: An alternative classification of trypanorhynch cestodes considering the tentacular armature as being of limited importance. Syst. Parasitol. 3: 81-92.

PEREIRA J. 1998: Trypanorhyncha (Cercomeromorphae, Eucestoda) nos Sciaenidae (Neopterygii, Perciformes) do litoral do Rio Grande do Sul: sistemática, estrutura das comunidades componentes e sua utilizção indicatores da estrutura trófica da assembléia hospedeira. $\mathrm{PhD}$ thesis, Univeridade Federal do Paraná, Brazil, 247 pp.

SCHOLZ T., GARIPPA G., SCALA A. 1993: Grillotia epinepheli sp. n. (Cestoda: Trypanorhyncha) plerocerci from the teleost, Epinephelus guaza, in Sardinia, Italy. Folia Parasitol. 40: 23-28.

SERET B., McEACHRAN J.D. 1986: Catalogue critique des types de poissons du Muséum national d'Histoire naturelle. Bull. Mus. Natl. Hist. Nat., Paris 4: 3-50. 